\title{
Association study of the lle349val polymorphism of the gene ADH1C and alcohol dependence
}

\author{
Estudo sobre a associação entre o polimorfismo lle349Val \\ do gene ADH1C e a dependência alcoólica \\ André Soares Rebelloํ, Rodrigo Moura-Neto2, Maria da Glória da Costa Carvalho ${ }^{3}$
}

\section{Keywords}

Alcohol dehydrogenase, polymorphism, chemical dependence, alcoholism.

\section{Palavras-chave}

Álcool desidrogenase, polimorfismo, dependência química, alcoolismo.

\begin{abstract}
Objective: The aim of this study was to investigate the polymorphism lle349Val of the enzyme alcohol dehydrogenase ADH1C gene among individuals with alcohol dependence syndrome (ADS) attending Alcoholics Anonymous (AA) meetings. Methods: A total of 120 subjects residing in Rio de Janeiro city participated in this study. Subjects were divided into two groups: a group consisting of 54 individuals from the ADS group and 66 individuals that declared not having any alcohol dependence (control group). DNA was extracted from mouth epithelial cells by phenol-chloroform method and further submitted to amplification by polymerase chain reaction (PCR). Results: Our results did not show differences between the genotypes of control individuals and ADS subjects. Nevertheless, we found increased rates of alcoholism in families of ADS subjects as compared to controls. Conclusions: Our results did not show any genotype difference on the ADH1C gene when control and AA genotypes are compared.
\end{abstract}

\section{RESUMO}

Objetivo: Investigar o polimorfismo lle349Val do gene ADH1C da enzima álcool desidrogenase e a dependência de álcool em indivíduos frequentadores dos Alcoólicos Anônimos (AA). Métodos: Um total de 120 pessoas residentes na cidade do Rio de Janeiro foi dividido em dois grupos: o primeiro foi formado por 54 pessoas com síndrome de dependência do álcool (SDA) pertencentes ao grupo dos AA. O segundo, com 66 pessoas, foi formado por indivíduos que descreveram não serem dependentes de álcool (grupo controle). O DNA foi extraído de células da mucosa oral utilizando-se a técnica do fenol-clorofórmio e posteriormente amplificado pela reação em cadeia pela polimerase (PCR). Resultados: Nossos resultados não mostraram diferenças entre o genótipo dos indivíduos controle e aqueles do grupo SDA. A análise, entretanto, demonstrou uma significativa relação entre o grupo SDA e o histórico familiar de alcoolismo. Conclusões: Em nossos resultados não encontramos diferenças quanto ao genótipo ADH1C em indivíduos com SDA e controles. 


\section{INTRODUCTION}

Alcoholism is a complex syndrome involving genetic, psychological and sociocultural factors ${ }^{1,2}$. Despite the genetic evidence associated with alcoholism, polymorphism studies with alcohol metabolism genes are still inconclusi$v^{3,4}$. The metabolism of ethanol occurs almost entirely in the liver and involves the oxidation to acetaldehyde by the enzyme alcohol dehydrogenase (ADH) and further to acetate by acetaldehyde dehydrogenase $(\mathrm{ALDH})^{5}$. The genes that encode these enzymes display polymorphism, which modulates individual differences in alcohol and acetaldehyde oxidizing capacity. Functional allelic variants of these genes result in enhanced catalytic activity (Vmax), increasing blood levels of acetaldehyde and, possibly, protection against alcoholism 6 .

The acetaldehyde is extremely toxic and produces the syndrome of "flushing" which is characterized by rubor faciale, tachycardia and somnolence, resulting in an aversion to alcohol and decreasing the risk of consumption? ${ }^{7}$. The set of enzymes called alcohol dehydrogenase complex (ADH) is the main responsible for the alcohol metabolism in the body, and have a very complex genetic and functional role. The various forms of the enzyme ADH are divided into five separate classes according to their subunits and also the composition of their isoenzimes. Genes for ADH are located on chromosome 4 and divided into 5 classes. The ADH1 class includes the genes $\mathrm{ADH} 1 \mathrm{~A}, \mathrm{ADH} 1 \mathrm{~B}$ and $\mathrm{ADH} 1 \mathrm{C}^{8,9}$. The $\mathrm{ADH} 1 \mathrm{C}$ gene has two isoforms: gamma1 and gamma2. The gamma1 isoform has an isoleucine at the codon 349 and an arginine at the codon 279 while the gamma2 isoform has a valine and a glutamine respectively. The gamma1 isoform codes for an enzyme that is two and a half times faster than the gamma2 isoform in ethanol metabolism, which causes a greater acetaldehyde accumulation ${ }^{10,11}$. The genes of human alcohol metabolism provide a rare example of how allelic variation contributes to a complex disease through intervening physiology and behavior.

The occurrence of these alleles depends on the population studied ${ }^{12}$. In South America, including Brazil, there are only a few published studies on the variation of the ADH1C gene. These studies involved the indigenous population ethnic groups Ticuna, Quechua and Suruí1 ${ }^{3}$. In Brazil, more specifically, Nishimoto et al. ${ }^{14}$ studied the lle349Val (rs698) polymorphism. However, these authors did not correlate their data with alcoholism but with cancer of the head and neck, since an association between the ADH1C gene polymorphism and aero digestive tract cancer was already reported.

Our study aims at investigating the lle349Val polymorphism (ref. SNP ID: rs698) of the gene ADH1C in individuals with alcohol dependence from Rio de Janeiro city, Brazil.

\section{METHODS}

\section{Samples}

A total of 120 subjects, aged $>50$ years, participated in this study. Participants were divided into two groups: a group consisting of 54 subjects with alcohol dependence syndrome (ADS), recruited ${ }^{15}$ in Alcoholics Anonymous meetings in Rio de Janeiro city, and a control group of with 66 convenience subjects. The control group was selected among the staff the Federal University of Rio de Janeiro and reported no history of problems with alcohol consumption. We chose control individuals older than 50 years based on the fact that alcoholism is more frequent in individuals between ages 20 and 50 .

We interviewed all participants using a structured questionnaire to obtain detailed information on demographic characteristics. Ethnicity was defined according to the information provided by the individuals. All participants signed an informed consent to participate in this study. This Project was approved by the medical ethical committee of the Federal University of Rio de Janeiro (protocol number: 069/07) in June $16^{\text {th }}, 2007$.

\section{Genotyping}

Genomic DNA was obtained from exfoliated cells. The brush containing the biological material was inserted into Eppendorf tubes containing $10 \mathrm{mM}$ TRIS-HCl buffer, $\mathrm{pH} 7.5$ in the presence of $10 \mathrm{mM} \mathrm{NaCl}, 2 \% \mathrm{SDS}$ and $15 \mu \mathrm{l}$ of proteinase (10 $\mathrm{mg} / \mathrm{ml}$ ). The material was incubated at $56^{\circ} \mathrm{C}$ for $2 \mathrm{~h}$ and DNA was extracted by phenol-clorophorm-isoamilic alcohol and resuspended in sterile distilled water.

The genotyping for the polymorphism of ADH1C was carried out by polymerase chain reaction (PCR) in $25 \mu \mathrm{l}$ of reaction mixture containing about 100 ng of genomic DNA, $100 \mathrm{ng}$ of each initiations, $200 \mathrm{mM}$ of dNTP, $2 \mathrm{mM} \mathrm{MgCl}_{2}, 50$ $\mathrm{mM} \mathrm{KCl}, 10 \mathrm{mM}$ TRIS-HCl (pH 8.41 and $0.5 \mathrm{U}$ of Taq DNA polymerase Applied Biosystems). The PCR amplification was performed using the following primers: A3FXNFOR1 (5'- TTG TTा ATC TGT GAT TाT TाT TGT-3'); A3FXNREV3 (5'-CGT TAC TGT AGA ATA CAA AGC-3').

The reactions were performed by incubating the mixture at $95^{\circ} \mathrm{C}$ for 5 minutes followed by 40 cycles at $95^{\circ} \mathrm{C}$ ( 1 second), $51^{\circ} \mathrm{C}$ ( 15 seconds), $72^{\circ} \mathrm{C}$ (75 seconds) and $72^{\circ} \mathrm{C}(10$ minutes). The PCR products were digested with 5 units of restriction enzyme Sspl in buffer recommended by the manufacturer (New England Corporation). Aliquots were subjected to electrophoresis in $10 \%$ polyacrylamide gels, stained with $0.1 \%$ silver nitrate solution and photographed on a light box using Polaroid film as described by Rebello and Carvalho, $2008^{16}$.

\section{Statistical analysis}

Differences in the characteristics of groups analyzed were estimated with Fisher's test, Epi Info program, using chi- 
-squared statistics, considering $5 \%$ as a significant value. The Hardy-Weinberg equilibrium was estimated by Fisher's Exact Test, using Genetic Data analysis Package, developed by Lewis and Zaykin ${ }^{17}$. Sampling sizing estimations were done as described by Budowle et al. ${ }^{18}$.

\section{RESULTS}

Table 1 shows the distribution of the number of subjects by gender, race and family history of alcoholism. The analysis of this data suggests the genetic nature of ADS, since the percentage of relatives with a history of alcoholism was significantly higher in ADS than in controls $(p<0.001)$.

Next, we characterized the genotype of subjects with respect to the lle349Val polymorphism of the gene ADH1C (Table 2A). There were no statistically significant differences $(p=0.80)$ in the distribution of genotypes between the control and ADS group. When comparing this distribution, there

Table 1. Distribution of subjects according gender, race and family of history alcoholism

\begin{tabular}{|c|c|c|c|}
\hline \multicolumn{4}{|c|}{ Subjects $N^{\circ}(\%)$} \\
\hline Variable & Control & ADS & p value* \\
\hline \multicolumn{4}{|l|}{ Gender } \\
\hline Male & $31(46,97)$ & $42(77,78)$ & 0,004 \\
\hline Female & $35(53,03)$ & $12(22,22)$ & \\
\hline \multicolumn{4}{|l|}{ Race } \\
\hline White & $51(77,27)$ & $43(79,63)$ & 0,73 \\
\hline Black & $15(22,73)$ & $11(20,37)$ & \\
\hline \multicolumn{4}{|c|}{ Family history** of alcoholism } \\
\hline Yes & $18(27,27)$ & $41(78,85)$ & 0,0001 \\
\hline No & $48(72,73)$ & $11(21,15)$ & \\
\hline
\end{tabular}

Table 2. Correlation between the ADH1C gene and the lle349Val polymorphism

\begin{tabular}{|c|c|c|c|}
\hline \multicolumn{4}{|l|}{ (A) } \\
\hline \multicolumn{4}{|c|}{ Subjects $N^{\circ}(\%)$} \\
\hline Genotype & Control & ADS & $p^{*}$ \\
\hline Ile.lle & $29(43,94)$ & $27(50,00)$ & \\
\hline Ile.Val & $30(45,45)$ & $22(40,74)$ & 0,80 \\
\hline Val.Val & $7(10,6)$ & $5(9,26)$ & \\
\hline \multicolumn{4}{|l|}{ (B) } \\
\hline Alleles & Control (66) & ADS (54) & $p^{* *}$ \\
\hline A & 0,651 & 0,704 & 1,00 \\
\hline G & 0,349 & 0,296 & 1,00 \\
\hline
\end{tabular}

was a low percentage of subjects with the genotype Val.Val in both groups. Also, we have counted the alleles and the frequency determined as depicted on table 2B. No departure from Hardy Weinberg Equilibrium were observed in both control and ADS groups $(p=1)$.

We then analyzed the male/female distribution according to the family history of alcoholism for each genotype (Table 3). For the genotype Val.Val, the number of individuals becomes too low when separated by gender. For this reason, the genotype lle.Val was added to this sample. There was a strong association between ADS individuals and a family history for male subjects.

Table 3. Correlation between the genotype distribution of individuals and familiar history of alcoholism

\begin{tabular}{|c|c|c|c|c|c|c|c|}
\hline \multicolumn{8}{|c|}{ Subjects $N^{\circ}(\%)$} \\
\hline & & \multicolumn{3}{|l|}{ Male } & \multicolumn{3}{|l|}{ Female } \\
\hline Genotype & $\begin{array}{l}\text { Family } \\
\text { history of } \\
\text { alcoholism }\end{array}$ & Control & ADS & $p^{*}$ & Control & ADS & $p^{*}$ \\
\hline \multirow[t]{2}{*}{ Ile.lle } & Yes & $4(26,66)$ & $18(75,00)$ & $4(28,57)$ & $1(33,33)$ & & \\
\hline & No & $11(73,33)$ & $6(25,00)$ & 0,0069 & $10(71,42)$ & $2(66,66)$ & 1,0 \\
\hline \multicolumn{8}{|l|}{ Val.Val } \\
\hline \multicolumn{8}{|l|}{+} \\
\hline \multirow[t]{2}{*}{ Ile.Val } & Yes & $1(6,25)$ & $13(81,25)$ & & $9(42,85)$ & $9(100)$ & \\
\hline & No & $15(93,75$ & $3(18,75)$ & 0,000019 & $12(57,14)$ & 0 & \\
\hline
\end{tabular}

ADS: alcohol dependence syndrome.

*Determined by exact Fisher test.

\section{DISCUSSION}

In this study, the allelic variation of the gene ADH1C Ile349Val in alcohol dependence was studied in a sample of the population of Rio de Janeiro city, Brazil. Admittedly, detailed clinical data on alcohol use, both in controls and in ADS subjects, were not obtained through a structured questionnaire. Therefore, the results of our study should be examined with caution. The lle349Val polymorphism was chosen because it is one of the least studied in the literature, particularly in South America, where such studies are restricted to the indigenous tribes in the Amazon region Quechua, Suruí and Ticuna ${ }^{13}$.

Literature data suggest that the distribution of genetic markers in the case of alcoholism is population specific. In the world distribution, $\mathrm{ADH}_{1} \mathrm{C}^{*} 1$ (ile.lle) has a frequency of $55 \%$ to $60 \%$ in Europeans descendants and $90 \%$ in the Chinese population ${ }^{19,20}$. In our study, we observed a small number of Val.Val individuals, and this is consistent with studies by Nishimoto et al. in a sample from Sao Paulo city. The authors, as already mentioned, studied the incidence of cancer of the upper aerodigestive tract, since the ADH1C gene is also associated with cancer of head and neck ${ }^{14}$.

When comparing ADS and control groups with regard to $\mathrm{ADH} 1 \mathrm{C}$ polymorphism, there was no difference between the 
two groups. This result was not surprising, since the Brazilian population is quite mixed and these relationships are strongly dependent on the population studied. The absence of ethnic differences in Brazilian population data confirms that there is no evidence of differences in genetic background based on the melanin concentration ${ }^{21}$. As noted, the number of subjects, though small, was considered adequate, since only one gene and two alleles were analyzed. Therefore, the minimum frequency of alleles with confidence level alpha $=$ 0.05 was 0.033 .

Francès et al. ${ }^{11}$, studying the Spanish Mediterranean population, also found no differences between genotype and alcohol consumption. When these authors, however, divided the population by gender, they found markedly increased ethanol consumption for the genotype Val.Val among females. These results were not observed in our study (data not shown).

The fact that ADS subjects have significantly more family history of alcoholism is in agreement with published literature ${ }^{1,2}$. Further, for each genotype, male patients with ADS exhibited increased family history of alcoholism. However, as our sample is restricted to the Rio de Janeiro city, these findings need to be analyzed with a larger sample, and also in populations from different regions of the country due to the strong racial mixture of the Brazilian population.

\section{CONCLUSIONS}

Our results showed no difference between the polymorphism rates of the enzyme alcohol dehydrogenase $\mathrm{ADH} 1 \mathrm{C}$ gene of control and the ADS group. We also find that individuals in the ADS group have a significantly greater number of alcoholic relatives than the control group.

\section{ACKNOWLEDGEMENTS}

This study was supported by the Conselho Nacional de Desenvolvimento Científico e Tecnológico and the Fundação Carlos Chagas Filho de Amparo à Pesquisa do Estado do Rio de Janeiro

\section{DISCLOSURE OF POTENTIAL CONFLICTS OF INTEREST}

No potential conflicts of interest were disclosed.

\section{REFERENCES}

1. Heath AC, Bucholz KK, Madden PA, Dinwidde SH, Slutske WS, Bierut LJ, et al. Genetic and environmental contributions to alcohol dependence risk in a national twin sample: consistency of findings in women and men. Psychol Med. 1997;27(6):1381-96.

2. Heath AC, Whitfield JB, Madden PA, Bucholz KK, Dinwiddie SH, Slutske WS, et al. Towards a molecular epidemiology of alcohol dependence: analyzing the interplay of genetic and environmental risk factors. Br J Psychiatry Suppl. 2001;40:33-40.

3. Dick DM, Foroud T. Candidate genes for alcohol dependence: a review of genetic evidence from human studies. Alcohol Clin Exp Res. 2003:27(5):868-79.

4. Enoch MA, Goldman D. Molecular and cellular genetics of alcohol addiction. In: Davis KL, Charney D, Coyle JT, Nemeroff C, editors. Neuropsychopharmacology: the fifth generation of progress. Philadelphia: Lippincott Williams and Wilkins; 2002, p. 1413-23.

5. Ramchandani VA, Bosron WF, Li TK. Research advances in ethanol metabolism. Pathol Biol. 2001;49(9):676-82.

6. Mulligan (J, Robin RW, Osier MV, Sambuughin N, Goldfarb LG, Kittles RA, et al. Allelic variation at alcohol metabolism genes (ADH1B, ADH1C, ALDH2) and alcohol dependence in a American Indian population. Hum Genet. 2003;113(4):325-36.

7. Harada S, Agarwal DP, Goedde HW, Tagaki S, Ishikawa B. Possible protective role against alcoholism for aldehyde dehydrogenase isozyme deficience in Japan. Lancet. 1982;2(8302):827.

8. Thomasson HR, Crabb DW, Edenberg HJ, Li TK. Alcohol and aldehyde dehydrogenase polymorphisms and alcoholism. Behav Genet. 1993;23(2):131-6.

9. Agarwal DP. Genetic polymorphisms of alcohol metabolizing enzymes. Pathol Biol. 2001;49(9):703-9.

10. Xu YL, Carr LG, Bosron WF, Li TK, Edenberg HJ. Genotyping of human alcohol dehydrogenases at the ADH2 and ADH3 loci following DNA sequence amplification. Genomics. 1988;2(3):209-14.

11. Francès F, Sorlí JV, Castelló A, Verdu F, Corella D, Portolés 0 . Genetic predisposition to alcohol consumption: the case of alcohol dehydrogenase 1C. Cuad Med Forense. 2007;13(4849):157-64.

12. Osier MV, Pakstis AJ, Soodyal H, Comas D, Goldman D, Odunsi A, et al. A global perspective on genetic variation on the $\mathrm{ADH}$ genes reveals unusual patterns of linkage disequilibrium and diversity. Am J Hum Genet. 2002;71(1):84-99.

13. http://alfred.med.yale.edu/alfred/recordinfo.asp?condition. sites=site uid=\$1000669V

14. Nishimoto IN, Pinheiro NA, Rogatto SR, Carvalho AL, Moura RP, Caballero OL, et al. Alcohol dehydrogenase 3 genotype as a risk factor for upper aerodigestive tract cancers. Arch 0tolaryngol Neck Surg. 2004;130(1):78-82.

15. Gigliotti A, Bessa MC. Síndrome de dependência do álcool: critérios diagnósticos. Rev Bras Psiquiatr. 2004;26(1):11-3.

16. Rebello AS, Carvalho MGC. Metodologia para estudo do polimorfismo do gene da enzima álcool desidrogenase. Rev Ciênc Méd Biol. 2008;7(2):163-8.

17. Lewis $\mathrm{PO}$, Zaykin D. Genetic data analysis: computer program for the analysis of allelic data; 2001. Available on: http://alley.eeb.uconn.edu/gda. Access on: Jul 1, 2010.

18. Budowle B, Monson KL, Chakraborty R. Estimating minimum allele frequencies for DNA profile frequency estimates for PCR-based loci. Int J Legal Med. 1966;108(4):173-6.

19. Agarwal DP, Harada S, Goedde HW. Racial differences in biological sensitivity to ethanol: the role of alcohol dehydrogenase and aldehyde dehydrogenase isozymes. Alcohol Clin Exp Res. 1981;5(1):12-6.

20. Xingguang L, Kranzler HR, Zuo L, Wang S, Schork NJ, Gelernter J. Diplotype trend regression analyses of the $A D H$ gene cluster and the ALDH2 gene: multiple significant association with alcohol dependence. Am J Hum Genet. 2006;78(6):973-87.

21. Pimenta JR, Zuccherato RW, Debes AA, Maselli L, Soares R, Moura-Neto RS, et al. Color and genomic ancestry in Brazilians: a study with forensic microsatellites. Human Heredity. 2006;62(4):190-5. 